\title{
FENOMENA IKLAN BARIS KESEHATAN DI SURAT KABAR LOKAL
}

\author{
Dadang Rahmat Hidayat, Aceng Abdullah \\ Program Studi Jurnalistik, Fakultas Ilmu Komunikasi, Universitas Padjadjaran
}

\begin{abstract}
ABSTRAK
Kebutuhan akan kesehatan dari masyarakat dimanfaatkan oleh para pelaku jasa kesehatan dengan mengiklankan jasa kesehatannya di media massa. Iklan-iklan yang menawarkan jasa kesehatan kian merebak baik di media cetak, radio dan televisi lokal. Di media cetak, umumnya mereka beriklan dalam bentuk iklan baris (iklan mini) yang tarifnya relatif murah. Jumlah iklan tersebut setiap hari di beberapa koran tertentu lumayan banyak pengiklan dengan menawarkan jasa pengobatan bermacam-macam seperti pengobatan alternatif, pijat refleksi, kebugaran badan, terapi, dan sebagainya.Penelitian yang menggunakan metode studi kasus dengan pendekatan kualitatif ini bertujuan untuk mengetahui regulasi mengenai iklan jasa kesehatan dan praktik jasa kesehatan yang diiklankan melalui iklan baris di media lokal di Bandung dan Surabaya. Simpulan dari penelitian ini menunjukkan bahwa regulasi yang berkaitan dengan iklan kesehatan di media massa yang belum komprehensif sehingga memberikan peluang adanya penyimpangan. Fenomena iklan baris kesehatan di koran lokal dapat memberikan informasi yang bermanfaat bagi kesehatan sekaligus berpotensi digunakan sebagai kedok bagi perilaku sosial dan bisnis menyimpang yang tidak berhubungan dengan kesehatan itu sendiri. Media massa koran tidak selalu dipertimbangkan kebenaran dari substansi iklan baris tersebut, justru pertimbangan ekonomi menjadi lebih penting.
\end{abstract}

Kata-kata Kunci: Surat kabar, regulasi, iklan baris, kesehatan, penyimpangan

\section{THE PHENOMENON OF HEALTHCARE CLASSIFIED ADS IN LOCAL NEWSPAPERS}

\begin{abstract}
The need for the health of society is being exploited by the health services company to advertise their services in the mass media. Ads that offer health services increasing rapidly in all print media, radio and local television. Generally, in the print media, health services advertise in the form of classified ads (line adverts), which has a relatively inexpensive rate. The daily amount of advertising in some specific papers reveal that quite a lot advertisers offering services such as the treatment of a variety of alternative treatments, reflexology, body fitness, therapy, and so on. This study uses case study method with qualitative approach aims to find out the regulations on advertising of health services and the practice of health services advertised through classified ads in the local media in Bandung and Surabaya.The conclusions of this study indicate that the regulations on healthcare advertisements in the mass media have not been comprehensively done, which provide opportunities for some misconduct. The phenomenon of healthcare classified ads in local newspapers would be able to provide useful information for health but has the potential to be used as a cover for social and business deviant behavior unrelated to health itself. Newspaper's financial consideration would disregard the substance truth of the classified ads.
\end{abstract}

Keywords: Newspaper, regulation, classified ads, health, irregularitie

Korespondensi: Dr. Dadang Rahmat Hidayat, S.Sos., S.H., M.Si. Program Studi Jurnalistik, Fakultas Ilmu Komunikasi, Universitas Padjadjaran. Jl. Raya Bandung-Sumedang KM.21 Email: dangerha2003@ yahoo.co.uk 


\section{PENDAHULUAN}

Kesehatan merupakan kebutuhan khusus bagi umat manusia. Hidup sehat menjadi dambaan setiap orang karena kualitas hidup dipengaruhi oleh tingkat kesehatan jasmani dan rohani seseorang. Mengatasi masalah kesehatan pun saat ini bukan hanya berupa tindakan pengobatan atau penyembuhan, tetapi aktivitas pencegahan pun sudah makin disadari oleh masyarakat, khususnya oleh masyarakat yang peduli dengan pentingnya masalah kesehatan

Seiring denganmakinkompleksnya masalah kesehatan dengan segala seluk beluknya, untuk pencegahan maupun pengobatan pun bukan hanya menggunakan pola medis modern tetapi juga dengan pola-pola tradisional, baik yang berasal dari leluhur kita sendiri, maupun pengobatan atau pencegahan secara tradisional dari negara-negara lain yang terkenal dengan keahliannya seperti dari negeri Cina.

Seiring dengan kemajuan teknologi komunikasi dan informasi serta kepemilikan sarana tersebut sudah hampir merata di kalangan masyarakat perkotaan, informasi masalah kesehatan ini pun dengan mudah didapatkan melalui internet. Untuk mencari apa saja yang berkaitan dengan masalah kesehatan, baik pengobatan maupun pencegahan dengan amat mudah orang tinggal mengklik di mesin pencari informasi.

Budaya hidup sehat ini pun bukan hanya terbatas pada pencegahan dan pengobatan, tetapi budaya hidup sehat saat ini sudah menjadi gaya hidup (life style). Jasa tenaga kesehatan pun digunakan bukan hanya untuk mengobati atau menghindari penyakit, tetapi kesehatan sekarang dalam arti luas dimaknai juga sebagai kebugaran, kecantikan, kegantengan, kesenangan serta kebahagiaan. Semuanya bermuara pada kepuasaan hidup. Itu sebabnya, barang dan jasa yang berkaitan dengan kesehatan pun sudah menjadi industri tersendiri dalam kehidupan modern sekarang.

Karena itulah, masyarakat kita semakin aktif untuk mencari informasi seputar pencegahan dan pengobatan suatu penyakit, khususnya bagi mereka yang kebetulan memiliki masalah kesehatan, bahkan konsultasi kesehatan pun sudah bisa dilakukan lewat internet secara gratis, tidak harus pergi ke tempat praktek dokter. Selain melalui internet, media massa konvensional seperti televisi, radio dan surat kabar memiliki acara atau halaman khusus tentang kesehatan ini, bahkan iklan TV, radio dan surat kabar pun sudah sejak lama menayangkan atau memuat tentang jasa kesehatan, bahkan iklan obat sejak industri farmasi berdiri sudah beriklan di media massa umum ini.

Makin besarnya kebutuhan hidup sehat masyarakat terhadap kesehatan jasmani ini dimanfaatkan oleh para pelaku jasa kesehatan, baik untuk pengobatan maupun pencegahan, khususnya non medis yang bersifat tradisional, untuk mengiklankan diri. Iklan-iklan yang menawarkan jasa kesehatan tradisional ini pun kian merebak baik di media cetak, radio dan televisi lokal. Umumnya mereka mengiklankan diri di media massa yang tarif iklannya murah. Untuk itu, media yang dipilih bukan media ternama, karena media ternama atau besar tarif iklannya lebih mahal.

Bagi penyedia jasa kesehatan kelas menengah atas, mereka mampu membayar spot acara khusus di stasiun televisi, radio atau memasang iklan display hingga 3 kolom di surat kabar. Tetapi ada pula pelaku jasa kesehatan yang hanya sanggup memasang iklan baris (iklan mini) yang bertarif murah. Jumlah mereka lumayan banyak, dalam setiap hari ada pengiklan yang menawarkan jasa pijat refleksi, kebugaran badan, terapi, dll. Para pemasang iklan baris ini umumnya bernama perempuan, ada yang menyebutkan alamat lengkap ada pula yang menawarkan jasa kesehatan panggilan dan hanya mencantumkan nomor telepon selular atau HP.

Banyaknya pengiklan jasa kesehatan perorangan ini, mengindikasikan pengguna jasa atau konsumen mereka juga jumlahnya banyak. Mereka memasang iklan setiap hari untuk jangka waktu lama. Iklan langganan seperti ini tarifnya jauh lebih murah ketimbang pemasang iklan baris secara harian.

Dari fenomena ini iklan baris jasa kesehatan memunculkan berbagai pertanyaan, siapakah mereka? Apakah mereka benarbenar menguasai atau ahli di bidang kesehatan tradisional ini seperti refleksi kaki, kebugaran badan, menyembuhkan penyakit ini dan itu? Mengapa hampir semua pengiklan ini bernama perempuan? Berapa tarif mereka? Siapakah pengguna jasa ini? Umumnya mereka dari kalangan mana? Apakah mereka puas dengan jasa kesehatan yang diberikan? Serta aneka pertanyaan lainnya. 
Berdasarkan aneka pertanyaan di atas, peneliti mengadakan penelitian atas kecenderungan ini dengan judul Fenomena Iklan Baris Kesehatan di Surat Kabar Lokal Bandung dan Surabaya.

Pemilihan tema iklan baris, karena peneliti belum menemukan penelitian lain tentang komunikasi kesehatan dengan objek penelitian iklan baris. Selama ini penelitian komunikasi kesehatan lebih banyak mengangkat iklan pengobatan di televisi atau pemberitaan kesehatan di surat kabar atau majalah. Banyak peneliti yang mengabaikan pemasang iklan baris, padahal dari segi kuantitas, jumlah mereka jauh lebih banyak dibanding pengiklan yang memasang secara display.

Selain itu, umumnya penelitian tentang media selalu menjadikan media besar atau media papan atas sebagai objek penelitian, padahal media lokal, seperti surat kabar lokal sangat jarang yang dijadikan sebagai objek penelitian terlebih iklan barisnya.

Penelitian ini merupakan penelitian awal, karena itu lingkup media massa yang diteliti pun adalah surat kabar lokal Bandung dan Surabaya. Fenomena iklan baris kesehatan ini bukan hanya terjadi di koran lokal Bandung dan Surabaya, tetapi juga ada di koran metropolis di kota-kota lain seperti Jakarta. Sebagai penelitian awal, Bandung dan Surabaya sebagai kota metropolitan diharapkan dapat mewakili kota-kota besar lainnya di Indonesia.

\section{METODE PENELITIAN}

Strategi penelitian yang digunakan dalam penelitian ini ialah studi kasus. Menurut Mulyana (2006: 201) studi kasus ialah uraian dan penjelasan komprehensif mengenai berbagai aspek seorang individu, suatu kelompok sosial, suatu organisasi (komunitas), suatu program atau situasi sosial. Peneliti studi kasus berupaya menelaah sebanyak mungkin data mengenai subjek yang diteliti.

\section{HASIL DAN PEMBAHASAN}

Setelah melakukan pengamatan langsung dan turun ke lapangan, penelitian dimulai dengan melakukan pengumpulan data-data mengenai regulasi tentang iklan kesehatan di surat kabar pada khususnya atau di semua media massa pada umumnya. Dari hasil pendataan tidak diketemukan regulasi khusus mengenai iklan baris kesehatan, kecuali mengacu kepadaEtika Periklanan Indonesia (EPI) Dewan Periklanan Indonesiaserta Peraturan Menteri Kesehatan RI No. 1787/Menkes/Per/XII/2010 tentang Iklan dan Publikasi Pelayanan Kesehatan.

Etika Periklanan Indonesia (EPI)adalah ialah ketentuan-ketentuan normatif yang menyangkut profesi dan usaha periklanan yang telah disepakati untuk dihormati, ditaati, dan ditegakkan oleh semua asosiasi dan lembaga pengembannya dan merupakan kumpulan berbagai perilaku periklanan yang menjadi landasan etik Tata Krama dan Tata Cara Periklanan bagi pelaku periklanan Indonesia yang dikeluarkan oleh Dewan Periklanan Indonesia (DPI) yang terdiri dari berbagai stakeholder periklanan di Indonesia seperti Persatuan Perusahaan Perikalanan Indonesia (PPPI), Serikat Penerbit Surat Kabar (SPS), Asosiasi Televisi Swasta Indonesia (ATVSI), Asosiasi Perusahaan Media Luar-griya (AMLI), Persatuan Radio Siaran Swasta Indonesia (PRSSNI).

Dijelaskan di dalam tujuan dan publik sasarandari EPI ini disebutkan bahwa Pedoman etika periklanan ini disepakati oleh pelaku periklanan untukdijadikan pedoman bersikap dan bertingkah laku secara internal, sehinggadalam berprofesi dan berusaha dapat senantiasa sesuai dengan nilai-nilaiyang dianut oleh masyarakat. Karena itu, pedoman etika periklanan ini akanpula dijadikan rujukan utama dalam segala upaya penegakannya, baiksecara internal maupun eksternal dalam hal terjadi keterkaitan dengan pihak-pihaklain.

Dengan penyepakatan tersebut diharapkan akan tercipta iklim berprofesidan berusaha yang adil, kondusif, inovatif, dan dinamis bagi kehidupan danpertumbuhan industri periklanan. Selanjutnya, iklim berprofesi dan berusahasedemikian diharapkan akan mendorong berkembangnya kegiatanberkomunikasi pemasaran yang bukan saja sehat dan bertanggung jawab,namun juga maju dan mutakhir. Pada gilirannya, semua ini akan melindungi konsumen, sekaligus meningkatkan integritas, harkat, dan martabat industriperiklanan secara keseluruhan. Dalam kaitan eksternal, pedoman etika periklanan ini bertujuan untukemberi informasi dan rujukan kepada masyarakat luas tentang hak-hakdan kualitas hidup khalayak yang terkait langsung 
maupun tak langsungdengan kiprah industri periklanan.

Bagi Pamong, pedoman etika periklanan ini seyogianya dijadikan rujukandalam segala upaya pembinaan industri periklanan.Sedang bagi lembaga pendidikan, ia perlu dijadikan materi ajar yang takterpisahkan dari studi komunikasi dan atau pemasaran.Selain para pihak itu, pedoman etika periklanan ini pun ditujukan kepadamasyarakat periklanan internasional.

Lingkup dari EPI ini meliputi dua hal yaitu Tatanan dan Keberlakuan. Tatanan EPI sebagai pedoman etika (code of ethics) periklanan ini disusundalam duatatanan pokok, yaitu tata krama (code of conducts) atau tatanan etika profesi, dan tata cara (code of practices) atau tatanan etika usaha. Meskipun demikian, keduanya beserta semua yang terkandung pada bagianbagian Pendahuluan, Mukadimah, Ketentuan, Penjelasan, Penegakan, dan Lampiran harus diperlakukan sebagai satu kesatuan utuh yang tak terpisahkan. Sedangkan Keberlakuan EPI ini berlaku bagi semua iklan, pelaku, dan usaha periklanan yang dipublikasikan atau beroperasi di wilayah hukum Republik Indonesia.

EPI secara umum mengatur segala jenis iklan termasuk yang berkaitan dengan kesehatan, antara lain mengenai Obatobatan, produk pangan, Vitamin, Mineral, dan Suplemen, produk Peningkat Kemampuan Seks, Kosmetika, alat kesehatan, alat dan Fasilitas Kebugaran atau Perampingan, Klinik, Poliklinik, dan Rumah Sakit, Jasa Penyembuhan Alternatif, Organ Tubuh Transplantasi dan Darah dan produk kesehatan terbatas.

Sementara itu Peraturan Menteri Kesehatan RI No. 1787/Menkes/Per/XII/2010 tentang Iklan dan Publikasi Pelayanan Kesehatan ini mengatur tentang iklan dan publikasi pelayanan kesehatan termasuk pelayanan kesehatan tradisional dan pengobatan komplementeralternatif, dengan demikian cukup luas.

Peraturan ini pun menyebutkan bahwa fasilitas pelayanan kesehatan dapat menyelenggarakan iklan dan dan/atau publikasi pelayanan kesehatan melalui media, namun ditegaskan bahwa publikasi tersebut harus sesuai dengan etika iklan dan/atau publikasi yang diatur dalam kode etik rumah sakit Indonesia, kode etik masing-masing tenaga kesehatan dan termasuk kode etik pariwara serta peraturan perundang-undangan yang berlaku.
Selanjutnya mengenai bentuk iklan kesehatan di surat kabar. Dari hasil pengamatan, bentuk iklan kesehatan di surat kabar dapat dibagi ke dalam 3 bentuk yaitu Iklan Berita (Advertorial), Iklan Display, dan Iklan Baris. Iklan baris dalam tampilan mempunyai ukuran yang lebih kecil dari iklan display, sementara iklan berita atau advertorial merupakan iklan yang dibuat menyerupai pemberitaan dengan maksud untuk lebih meyakinkan audience.

Istilah atau penamaan iklan baris kesehatan dapat disebutkan setidaknya dengan istilah Kesehatan, Pengobatan, Pijat, Pijat Kebugaran, dan Paranormal. Istilah yang digunakan memang beragam seiring dengan beragamnya perspektif dan kebijakan setiap surat kabar yang bersangkutan.

Selanjutnya mengenai kebijakan media dan realitas iklan baris di koran lokal Bandung dan Surabaya. Iklan bagi media massa merupakan salah satu bagian penting dan bahkan utama untuk menjalankan roda kehidupan media tersebut. Semua media massa berusaha untuk mendapatkan iklan yang sebanyak-banyaknya atau keuntungan sebesar-besarnya. Pendapatan media diluar iklan dapat berupa kegiatan off air bagi lembaga penyiaran atau penjualan tiras bagi media massa cetak.

Kebijakan media dalam mendapatkan iklan dijalankan dengan berbagai strategi. Strategi media sangat dimungkinkan sama dan atau berbeda satu sama lain, tergantung kondisi, kedudukan media (lokasi), kompetitor dan segmen dari media itu sendiri. Demikian pula dengan koran lokal, dalam hal ini koran lokal yang menjadi objek penelitian ini, yaitu koran Tribun dan Pikiran Rakyat di Bandung serta koran Memorandum (Memo) di Surabaya. Termasuk mengenai kebijakan pemuatan iklan baris yang berkaitan dengan kesehatan. Dinamika dan kebijakan koran-koran tersebut adalah sebagai berikut: (1) Urgensi Iklan Baris Kesehatan. Iklan baris kesehatan ternyata mempunyai sumbangan yang cukup besar bagi pendapatan iklan di berbagai koran karena pengiklan sebagian besar berlangganan untuk waktu tertentu dan cukup lama. Meski relatif murah namun karena terus menerus maka bagi koran-koran tersebut sudah mendapatkan kepastian pendapatan, (2) Harga Iklan. Harga iklan baris kesehatanberlangganan bervariasi berkisar 125-200 ribu untuk satu minggu dan sebagian besar diperpanjang, terutama 
iklan kesehatan yang berkaitan dengan pijat (kebugaran). Pengiklan iklan baris kesehatan ada yang langsung menghubungi pemasaran koran-koran serta ada juga yang mengggunakan agen-agen iklan, (3) Seleksi iklan baris kesehatan berdasar norma-norma tidak terlalu dihiraukan, (4) Kerawanan Iklan Baris Kesehatan. Iklan baris kesehatan di koran-koran pada umumnya dan khususnya di koran yang diteliti tidak selalu memberikan gambaran dan pengaruh positif, namun dapat mendatangkan permasalah atau kerawanan, antara lain: (a) Tidak terjaminnya informasi pelayanan kesehatan. Informasi yang disampaikan beberapa iklan kesehatan tidak dijamin kebenarannya, menjanjikan kesembuhan dan sebagainya dengan tidak menyampaikan fakta atau data yang dapat dipertanggungjawabkan, (b) Tidak adanya izin dan pengawasan dari instansi yang bertanggungjawab dengan masalah kesehatan. Sebagian besar iklan kesehatan tidak mencantumkan izin praktek atau izin pengobatan dari instansi bewenang dalam masalah kesehatan, hal ini seringkali tidak menjadi konsern bagi media. (c) Kedok bagi penyimpangan sosial seperti penipuan pelayanan kesehatan dan prostitusi.Kerawanan yang paling menonjol adalah dengan adanya penyalahgunaan iklan baris kesehatan dengan kategori iklan pijat yang sebagian besar merupakan kedok bagi penyimpangan sosial. Dalam hal ini para pengelola sering mengelak mengenai adannya pembiaran terhadap iklan seperti ini, dengan dalih bahwa urusan lainnya selain klan pijat itu urusan pengiklan dengan kliennya.

Secara khusus peneliti melakukan penelusuran mengenai kerawanan iklan baris seperti ini, dan mendapatkan informasi sebagai berikut: (1) Informasi dari koran lokal di Bandung dan Surabaya. (a) Memorandum (Memo) Surabaya.Memorandum adalah salah satu harian yang ada di Surabaya, selain Jawa pos, Surya, Radar, Birawa, Surabaya Pagi (Post) dan beberapa harian lainnya. Memorandum termasuk koran yang cukup tua di Surabaya dan sejak 1991 masuk dalam Group Jawa Post.

Memo yang saat ini bertiras sekitar 17.000 eksemplar, sesungguhnya pernah mencapai tiras sampai 90.000 eksemplar. Memo menyatakan bahwa dialah satu-satunya "koran kuning" di Surabaya dengan segmentasi SES menengah ke bawah, sehingga tidak memiliki pesaing, karena koran lainnya merupakan "koran putih". Dengan demikian segmen ini dianggap menyukai berita-berita kriminalitas, hukum dan sensasional. Berdasar ini pula iklan-iklan di Memo lebih berkaitan dengan segmen tersebut, semisal pengobatan alternatfSetiap hari ada puluhan pengiklan yang berkaitan dengan jasa kesehatan dan pengobatan. Mungkin karena penyakit di masyarakat makin beragam dan pengobatan ke rumah sakit makin mahal.

Manajer Iklan Harian Memorandum Sumaryadi menyatakan bahwa tarif iklan mini atau iklan baris di Memo dibanding koran lain, iklan di Memo termasuk yang termurah. Tetapi jika pengiklan memasang terus menerus ternyata menguntungkan juga. Daripada tarifnya mahal, tetapi hanya sekali dua kali muat dalam setahun. Sedangkan dengan strategi pentarifan iklan di Memo, si pemasang iklan bisa memasang iklan sepanjang tahun. Iklan baris juga murah, tapi jika memasang sepanjang tahun jadi menguntungkan. Iklan mini atau baris cukup murah, hanya $\mathrm{Rp} 125$ ribu sampai Rp 150 ribu perminggu. Sebulan bisa Rp 500 ribu sampai Rp 600.000. Kalau setiap hari ada 50 pemasang maka omset iklannya bisa mendapat 25 sampai 30 juta rupiah.Untuk iklan display, Sumaryadi menjelaskan bahwa iklan display pengobatan alternatif juga tarifnya untuk satu minggu. Setiap minggu 1,25 juta rupiah untuk hitam putih dan 1,5 juta rupiah untuk berwarna, sehingga setiap bulan tarifnya antara 5 juta sampai 6 juta rupiah per bulan.

Mengenai efektivitas iklan diyakini efektif karena jika tidak efekif, mungkin mereka tidak akan memasang iklan terus menerus sepanjang tahun. Penghasilan mereka dipastikan bisa berlipat-lipat dari biaya iklan yang mereka keluarkan.Sumaryadi mengakui bahwa dari puluhan iklan yang dimuat selama bertahuntahun. Pernah satu kali ada yang komplain tetapi setelah itu tidak pernah ada lagi. Kita punya komitmen jika satu iklan diprotes banyak pihak, maka iklan itu akan dihentikan. Diakuinya juga bahwa iklan Panti Pijat, Sejak iklan ini muncul bertahun-tahun belum pernah ada protes atau larangan iklan itu. Pernah ada yang protes dari pembaca, bukan masalah keberadaan iklannya, tetapi Orang yang mengiklan diri tidak sesuai fakta. Ngakunya Cina, ternyata bukan Cina. Ngakunya rambut pirang ternyata hitam. Ngaku tinggi dan cantik ternyata pendek dan tidak cantik. Iklan-iklan seperti ini tidak hanya hanya 


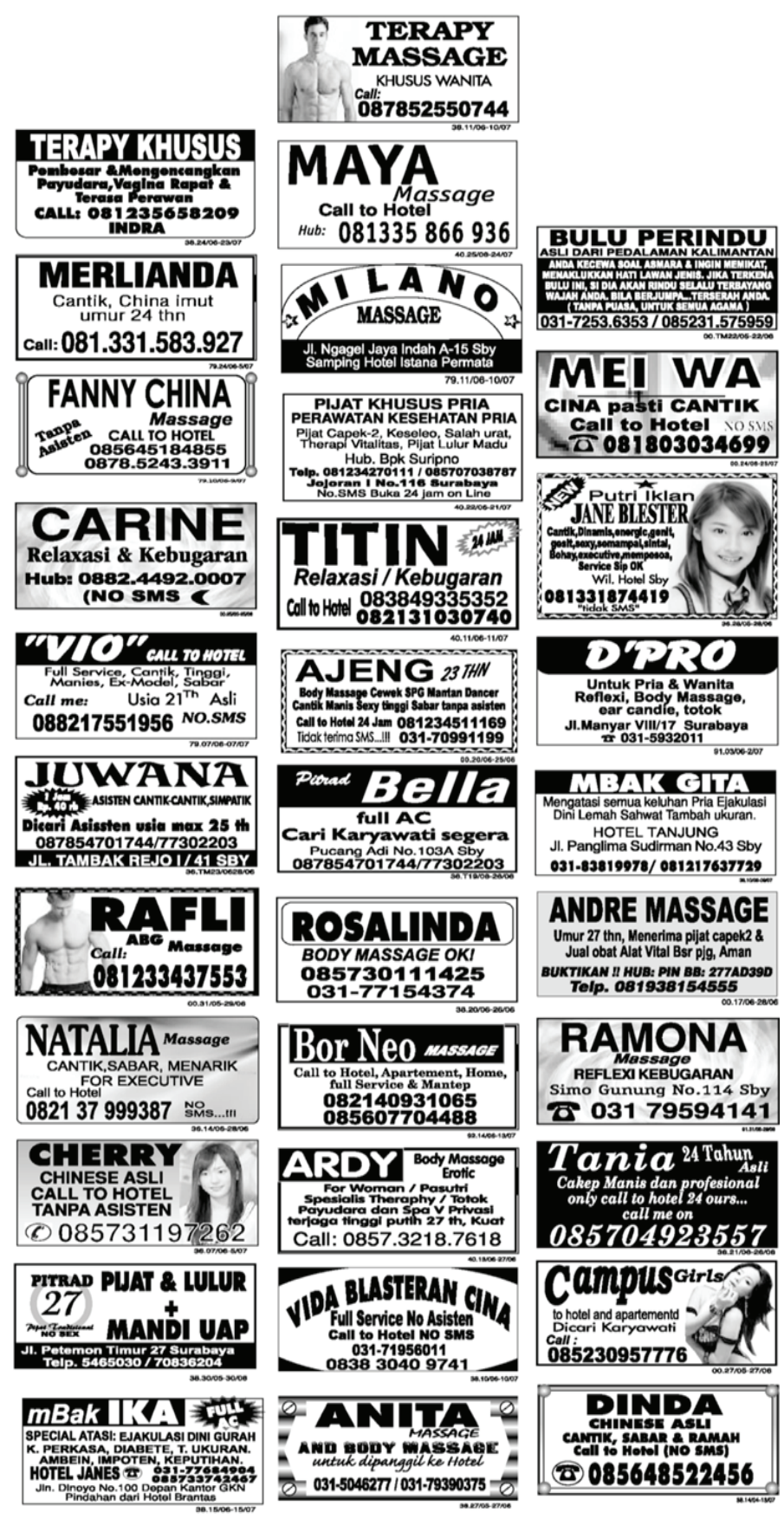

Gambar 1 Contoh Iklan Baris Memorandum

ada di Memo, di "koran putih" seperti Surya, iklan seperti ini ada juga. Tetapi mereka lebih sopan dengan istilah-istilah yang tidak lugas seperti di Memo. Misalnya menggunakan istilah Herbal, terapi dan sebagainya. Iklan jasa "pijat" sudah ada sejak lama. Sejak tahun 90-an. Jadi tidak ada hubungannya dengan penutupan Dolly. Tetapi tidak seramai sekarang. Beberapa tahun lalu iklan Memo didominasi oleh iklan Party Line.

(b) Surat Kabar yang kedua yaitu Pikiran Rakyat Bandung. Harian Umum Pikiran Rakyat
Bandung adalah koran terbesar di Bandung dan Jawa Baratsampai saat ini. Ada beberapa hal yang mendasari kebijakan periklanan di Harian Umum Pikiran Rakyat, termasuk iklan kesehatan. Menurut manajer iklan Harian Umum Pikiran Rakyat Refa Riana menyebutkan bahwa iklan yang dimuat di Pikiran Rakyat mengacu kepada Kode Etik Periklanan Indonesia. Jika secara kode etik sudah oke, bagi PR tidak jadi masalah.

Ada juga kebijakan perusahaan di luar kode etik periklanan tersebut, yakni untuk 


\section{pengobatan \\ ANDA STROKE. Hubung: 081220091556 - 087821830955 \\ Gemuk\&PerutBuncit $P$ /WrTurun \\ 3-6Kg/BI DgnJamu"Bu Slamet" Bahureksa 8 T.(022)4203876 \\ HILANG TOTAL\& TDK KAMBUH LG TANPA OPERASI. KLINIK WASIR PURWAKARTA 99(ATPN) 77279174 \\ PILBIRU_KUAT,PRCOMILNANGEN PLANGSING,PEMUTIH,GEMUK BDN VEGINATOR,FULBODY,VACUM P/W T.6047 123,ANTAR 0818159026 \\ penterjemah \\ Jasa Terjemah Buku2dil 8Bhs \\ TSumpah Sms/0896 09764009 \\ pijat \\ MariaMsgTerapi/LulurTmpNymn Gatsu45B.082240260091,NoSMS \\ PUAT TRDSL TrmPgg. LUMBUNG 4/43 CARINGIN.081271274005 \\ PijatKebugaran DHEA MASSAGE Di Tmpt/Pggin-081220959469 \\ AHLI PUAT URUT PGB "BU MIRA' PGL. T:0813 21116206 PUAT TRADISIONAL,PIIIn \\ JLA.Yani121 T.082319381530 UNIQUE SPA \& CAFE THE BEST MASSAGE QUALITY CIATEUL. 141 BDG T.73903000

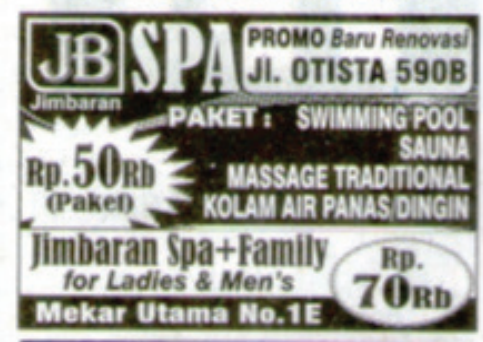

\section{Gambar 2 Contoh Iklan Baris Pikiran Rakyat}

pemuatan iklan sengketa (kasus perdata) hanya bisa dipasang jika sudah ada kekuatan hukum pasti. Artinya kasus itu sudah selesai di tingkat pengadilan negeri. Jika kasusnya belum selesai, jangan harap iklan sengketa bisa dimuat. Hal ini untuk menghindari pemanfaatan media oleh salah satu pihak yang tengah bersengketa di pengadilan.

Mengenai iklan kesehatan seperti pengobatan alternatif seperti iklan obat kuat tidak akan bisa dimuat. Iklan seperti ini produknya seperti membodohi masyarakat. Juga iklan-iklan pengobatan alternatif yang di

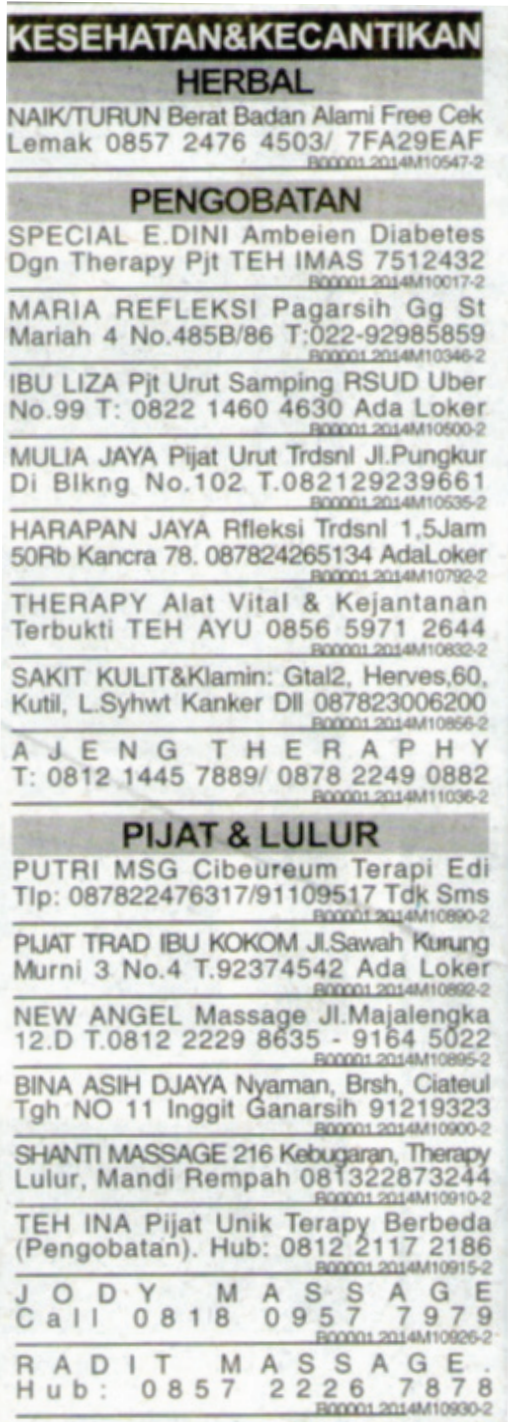

\section{Gambar 3 Contoh Iklan Baris Surat Kabar Harian Tribun Jabar}

koran lain bisa berderet berhalaman-halaman, di PR tidak menerima ini. Hal ini karena PR bukan koran kuning. Iklan seperti pengobatan alternatif yang kabarnya bisa menyembuhkan penyakit apa saja dari mulai penyakit yang berat sampai penyakit ringan tapi tidak bisa sembuh oleh dokter.

Kebijakan di atas tentu karena segmenetasi pembaca PR sangat berbeda degan segmentasi koran lain yang jor-joran dengan menarik iklaniklan pengobatan alernatif ini.

Mengenai iklan Pijat, PR mengkategorikannya sebagai iklan kesehatan. Pijat refleksi misalnya sudah terbukti tidak ada unsur penipuannya. Tetapi kalau pengobatan alternatif yang kabarnya bisa menyembuhkan segala macam penyakit, dan ternyata tarifnya mahal, itu tentunya sudah membodohi 
masyarakat.

PR mengakui bahwa belum pernah dikomplain masalah iklan. Yang komplain justru pemasang iklannya karena ternyata segmentasi pembaca PR beda. PR dikomplain pemasang iklan premium, ternyata segmentasi pembacanya lain.

Surat Kabar yang ketiga yaituTribun Jabar. Harian Umum Tribun Jabar adalah koran lokal yang berafiliasi dengan Kompas Group. Informasi mengenai iklan kesehatan di harian umum Tribun didapatkan melalui pengamatan bahwa Tribun Jabar juga memuat iklan kesehatan termasuk iklan dengan kategori baris dan display.

Iklan kesehatan pengobatan alternatif dan pijat juga mempunyai tempat yang "baik" di harian Tribun Jabar ini. Peneliti menduga bahwa segmentasi dari Tribun Jabar ini adalah menengah ke bawah, sementara menengah atasnya digarap langsung oleh Harian Umum Kompas.

Pada Harian Umum Tribun Jabar iklan kesehatan tidak hanya iklan baris tetapi juga iklan display. Pada kategori iklan baris terdapat istilah kesehatan kecantikan, pengobatan, pijat dan lulur. Hal unik adalah iklan baris disebutkan sebagai iklan Favorit dengan tagline "Buat apa bayar mahal kalau hasilnya sama”. Dengan demikian Tribun Jabar mengklaim bahwa iklan baris mereka lebih murah di banding harian lainnya di Bandung.

Informasi dari pengiklan. Setiap pengiklan mempunyai pertimbangan atau alasan mengapa mereka menempakan iklannya di suatu media, termasuk juga mengapa mereka terus menerus atau menarik iklannya, salah satunya berkaitan dengan harga iklan dan efektivitas iklan tersebut. Demikian pula pelanggan pengiklan kategori kesehatan yang dalam hal ini peneliti dapatkan dari pengiklan pijat di Bandung dan Surabaya, yang peneliti dapatkan dari nomor HP yang pengiklan sebutkan dalam iklannya yang dimuat.

Seorang pengiklan yang bernama Talitha (samaran) adalah pemijat yang telah menjalani pekerjaanya selama 5 tahun dengan alasan kepepet ekonomi, berpisah dengan suami dan harus membiayai anaknya.Talitha mendapat keahlian memijatnya dari majikan pada saat bekerja di Panti Pijat. Sebelumnya dia bekerja di PP. Sebelum praktik, diajari dulu bagaimana cara memijat. Yang menurut pengakuannnya yang datang bukan hanya ingin dipijat, kebanyakan ingin"diterapi" atau "plus-plus" (lebih dari sekedar pijat).

Selanjutnya setelah tiga tahun bekerja di Panti Pijat, merasa pendapatannya tidak besar dan kemudian berinisiatif untuk bekerja sendiri dengan harapan mendapatkan pendapatan yang lebih besar. Namun untuk bekerja sendiri ada beberapa yang disiapkan termasuk modal sendiri untuk sewa kost dan pengeluaran bulanan, termasuk modal untuk "pasang iklan mingguan".

Talitha melakukan itu setelah mendapatkan informasi dari temannya yang telah lebih dulu melakukan kerja sendiri, termasuk informasi cara-cara mengiklankan dirinya dengan memilih iklan mini atau baris di koran. Setelah dia beriklan ternyata banyak terima telepon "klien" yang ingin mendapatkan jasanya.

Sebagian besar yang menghubunginya ingin mendapatkan informasi seperti umur, tarif, jenis layanan dan sebagainya. Menurutnya ini adalah pertanda kesuksesan pekerjaannya.Talitha memilih berlangganan memasang iklan baris mingguan di koran lokal di Bandung. Untuk dua baris tarifnya 125 ribu untuk seminggu. Jadi sebulan 500 ribu buat iklan aja. Kalau tidak begitu khawatir tidak mendapatkan tamu. Talitha menggunakan agen iklan dan agenlah yang menjemput materi iklan dan meminta bayaran, sehingga dia tidak perlu datang sendiri ke koran yang dimaksud. Materinya biasanya berisi nama yang biasanya nama yang "keren" atau "seksi" dan pasti nama samaran, ciriciri singkat, layanan dan nomor telepon yang bisa dihubungi. Meski mencantumkan nomor telepon (HP), Talitha tidak melayani SMS tapi hanya telepon langsung, untuk melayani yang serius dengan tarif 150 ribu rupiah per dua jam.

Informasi dari konsumen pengiklan.Untuk melengkapi seperti apa respons masyarakat atau lebih khusus "peminat" yang menjadi klien dari pemasang iklan baris kesehatan. Peneliti mendapatkan klien yang juga mengetahui tentang iklan yang dimaksud. Informan ini sebut saja namanya XYZ (52 tahun) seorang pegawai swasta.

XYZ mengetahui layanan dari pemijat plus dari koran lokal di Bandung seperti Tribun, Radar dan Pikiran Rakyat. Setelah mengetahui dia mengontaknya, hal ini telah dia lakukan sejak 5 tahun yang lalu. Menurut XYZ percaya 
bahwa iklan kesehatan pijat sesungguhnya merupakan pengantar terhadap prostitusi terselubung, pijat yang ditawarkan tapi ujungujungnya pada pelayanan plus. Pijat, sauna dan spa sering kali jadi kedok saja, meski ada juga yang benar sesuai aturan atau norma yang ada.

XYZ mengetahui tarif layanan yang menurutnya tergantung kualitas pemijatnya, biasanya makin berkualitas makin mahal. Negosiasi menjadi penting juga untuk menentukan tarif. Lokasi juga menentukan tarif. Keahlian memijat sesungguhnya tidak menjadi penting menurutnya.

XYZ merasa heran juga bahwa para pemijat tersebut berani mengiklankan, bagaimana kalau yang datang sebagai pelanggan tersebut orang yang ternyata kenal. XYZ yang telah memasuki dunia ini sejak tahun 2009, sepengetahuannya diawali dengan iklan Spa atau Sauna kemudian panti pijat dan sekarang ada yang mandiri atau "one person show". Menurut XYZ biaya iklan mereka sebenarnya sangat murah jika dibandingkan potensi pendapatan akibat dari keterkenalan mereka dengan mengiklankan dirinya. Dari yang diketahuinya bagi pemijat yang baik dan cantik bisa mendapatkan tamu sampai 5 pelanggan perhari dengan rata-rata di atas 200 ribu per pelanggan. Dengan demikian iklan seperti itu cukup efektif. Bahkan sekarang media mereka lebih terbuka dengan media sosial yang mereka pakai.

Namun demikian, XYZ yang juga berada di dunia media merasa miris karena iklan seperti ini biasanya berada di media yang relatif dijual murah.Maraknya iklan seperti ini di Bandung menurut XYZ bisa juga diakibatkan penutupan Saritem. Mereka menyebar ke mana-mana. Ada yang ke Spa, Panti pijat, Sauna, Karaoke, atau Klab malam.

Dengan mengamati bentuk dan jenis iklan baris kesehatan, penelitian telah menemukan data-data sebagai berikut: (1) Hampir semua media massa cetak, khususnya surat kabar menampilkan iklan baris sebagai bagian dari slot iklan secara umum, (2) Beberapa surat kabar secara jelas membuat klasifikasi iklan baris dengan klasifikasi "kesehatan" sebagian lainnya menggunakan istilah berbeda, (3) Kolom iklan baris kesehatan di beberapa surat kabar terdapat "kesaruan" dengan iklan pengobatan dan atau rekreasi, (4) Bentuk dan jenis iklan baris kesehatan berkaitan dengan segmentasi dari surat kabar yang bersangkutan

\section{SIMPULAN}

Fenomena iklan baris kesehatan di koran lokal dapat memberikan informasi yang bermanfaat bagi kesehatan dalam arti sesungguhnya. Namun ditemukan juga indikasi bahwa iklan baris kesehatan hanya sebagai jalan atau kedok untuk menjalankan bisnis lain yang lain atau tidak berhubungan dengan kesehatan bahwa dapat dikatakan sebagai perilaku menyimpang.

Media massa koran ternyata juga memanfaatkan kolomnya untuk dijadikan iklan baris kesehatan yang tidak selalu dipertimbangkan kebenaran dari substansi iklan baris tersebut. Mungkin karena adanya pertimbangan ekonomi yang penting kolomnya adanya yang beriklan.

Saran dari penelitian ini diantaranya: (a) Media massa tidaklah berada di ruang hampa, namun berada di tengah ruang publik, sehingga disarankan untuk tetap melakukan seleksi terhadap semua materi iklan yang dimuat di medianya, termasuk iklan baris kesehatan yang diantaranya terindikasi penyimpangan sosial, publik wajib menerima informasi yang benar dan layak serta bermanfaat, (b) Perlu adanya pengawasan khusus dari lembaga yang terkait kewenangannya agar media massa tidak dijadikan sarana penyimpangan, dan (c) Secara umum penelitian ini tidak ada masalah, hanya dalam hal penelitian yang berkaitan dengan cara yang tidak terbuka untuk mendapatkan informasi, sangat dimungkinkan ada pengeluaran biaya penelitian yang tidak ada bukti pertanggungjawabannya, sehingga perlu dipertimbangkan jenis pertanggungjawaban yang tidak hanya formal administratif namun secara substansial dan moral bisa dipertanggungjawabkan.

\section{DAFTAR PUSTAKA}

Lindlof, T. R.(1995).Qualitative communication research methods. Thousand Oaks, CA: Sage Publication Inc.

McQuaill, D. (1987). Mass communication theory. London: Sage Publication Inc

Muhadjir, N. (1996). Metodologi penelitian kualitatif. Yogyakarta: Rake Sarasin.

Mulyana, D. (2006). Metodologi penelitian kulaitatif. Bandung: Remaja Rosda Karya. 
Musman, A.\& Sugeng, W.A. (2011). Marketing media penyiaran (bukan sekedar kecap). Yogyakarta. Cahaya Atma Pustaka.

Trisnanto, A. (2007). Cerdas beriklan.
Yogyakarta. Galang Press.

Winarno, B. (2008). Rumah iklan. Jakarta. Kompas. 